\title{
Sperm donation and surrogacy from a Male perspective
}

\author{
Naír Carolino1, Ana Galhardo,2, Mariana Moura-Ramos², Marina Cunha1,2 \& Bárbara Monteiro ${ }^{1}$ \\ ${ }^{1}$ Instituto Superior Miguel Torga \\ ${ }^{2}$ CINEICC - Faculty of de Psychology and Educational Sciences of the University of Coimbra
}

\section{Introduction}

Society and culture are facing a period of transformation and adaptation to new paradigms, where gender equality is seeking for a place. Fertility/infertility studies have focused mainly on the female partner, the male being less studied (Hanna \& Gough, 2015). More recently, fertility related aspects have been conceptualized from a couple perspective. However, there is a lack of studies addressing men's attitudes regarding Assisted Reproductive Technologies (ART) in general population. ART legislation varies according to the country and Portugal has recently approved the extension of access to ART for all women. Nevertheless surrogacy is only allowed in cases of absence of uterus, injury or disease of this organ, which prevents an absolute and spontaneous pregnancy. It is also necessary to emphasize the importance of gamete donation and the men's attitudes regarding this subject, due to its impact for Portuguese sperm banks. Thus, it is relevant to know more about men's perspective concerning ART.

\section{Materials}

Participants: 111 males with ages ranging from 18 to 40 years old $(M=27,99 ; S D=5,38)$, without children and with a mean of years of education of $14.76(S D=2.30)$. The majority are single $(79.5 \%)$ and are employed $(63.1 \%)$.

Materials: An online questionnaire addressing attitudes toward gamete donation and surrogacy was developed for this study. Procedures: Participants were recruited by e-mail through a snow-ball procedure. The aims and inclusion criteria for participating in the study and the link to acess the platform were included in the e-mail. The informed consent was request.

\section{Results}

\begin{tabular}{|c|c|c|c|c|c|}
\hline \multicolumn{4}{|c|}{ Would you consider the possibility of donating sperm? } & \multicolumn{2}{|l|}{$n(\%)$} \\
\hline \multicolumn{4}{|l|}{ Yes } & \multicolumn{2}{|c|}{$92(82,9 \%)$} \\
\hline \multicolumn{4}{|l|}{ No } & \multicolumn{2}{|c|}{$19(17,1 \%)$} \\
\hline What do you think about gamete donation? & $\begin{array}{c}1 \\
\text { Tottaly } \\
\text { disagree }\end{array}$ & 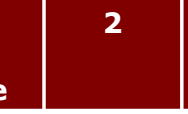 & 3 & 4 & $\begin{array}{c}5 \\
\text { Tottaly } \\
\text { agree }\end{array}$ \\
\hline $\begin{array}{l}\text { If a friend wanted to donate gametes to another couple I would } \\
\text { support his decision. }\end{array}$ & & $\begin{array}{c}4 \\
(3,6 \%)\end{array}$ & $\begin{array}{c}19 \\
(17,1 \%)\end{array}$ & $\begin{array}{c}32 \\
(28,8 \%)\end{array}$ & $\begin{array}{c}56 \\
(50,5 \%)\end{array}$ \\
\hline If a friend wanted to receive gametes, I would support his decision. & & $\begin{array}{c}3 \\
(2,7 \%)\end{array}$ & $\begin{array}{c}20 \\
(18,0 \%)\end{array}$ & $\begin{array}{c}32 \\
(28,8 \%)\end{array}$ & $\begin{array}{c}56 \\
(50,5 \%)\end{array}$ \\
\hline $\begin{array}{l}\text { Gamete donation is a good way to help couples that cannot have } \\
\text { children. }\end{array}$ & $\begin{array}{c}1 \\
(0,9 \%)\end{array}$ & $\begin{array}{c}2 \\
(1,8 \%)\end{array}$ & $\begin{array}{c}18 \\
(16,2 \%)\end{array}$ & $\begin{array}{c}39 \\
(35,1 \%)\end{array}$ & $\begin{array}{c}51 \\
(45,9 \%)\end{array}$ \\
\hline What would motivate/discourage you from donating sperm? & $? \begin{array}{c}1 \\
\text { Tottaly } \\
\text { disagree }\end{array}$ & 2 & 3 & 4 & $\begin{array}{c}5 \\
\text { Tottaly } \\
\text { agree }\end{array}$ \\
\hline Happy to help a couple struggling to have a child. & & $\begin{array}{c}1 \\
(1,1 \%)\end{array}$ & $\begin{array}{c}13 \\
(14,1 \%)\end{array}$ & $\begin{array}{c}26 \\
(28,3 \%)\end{array}$ & $\begin{array}{c}52 \\
(56,5 \%)\end{array}$ \\
\hline As if I was contributing in an altruistic way. & $\begin{array}{c}5 \\
(5,4 \%)\end{array}$ & $\begin{array}{c}15 \\
(16,3 \%)\end{array}$ & $\begin{array}{c}26 \\
(28,3 \%)\end{array}$ & $\begin{array}{c}20 \\
(21,7 \%)\end{array}$ & $\begin{array}{l}26 \\
(28,3 \%)\end{array}$ \\
\hline Apprehensive with the possibility to be contacted later. & $\begin{array}{c}37 \\
(40,2 \%)\end{array}$ & $\left(\begin{array}{c}22 \\
(23,9 \%)\end{array}\right.$ & $\begin{array}{c}17 \\
(18,5 \%)\end{array}$ & $\begin{array}{c}8 \\
0) \quad(8,7 \%)\end{array}$ & $\begin{array}{c}8 \\
(8,7 \%)\end{array}$ \\
\hline How would you feel if you had to use donor gametes? & $\begin{array}{c}1 \\
\text { Tottaly } \\
\text { disagree }\end{array}$ & 2 & 3 & 4 & $\begin{array}{c}5 \\
\text { Tottaly } \\
\text { agree }\end{array}$ \\
\hline Glad to take care of a child since birth. & $\begin{array}{c}8 \\
(7,2 \%)\end{array}$ & $\begin{array}{c}7 \\
(6,3 \%)\end{array}$ & $\begin{array}{c}16 \\
(14,4 \%)\end{array}$ & $\begin{array}{c}45 \\
(40,5 \%)\end{array}$ & $\begin{array}{c}35 \\
(31,5 \%)\end{array}$ \\
\hline Happy to fulfill my dream of being a father. & $\begin{array}{l}10 \\
(9,0 \%)\end{array}$ & $\begin{array}{c}14 \\
(12,6 \%)\end{array}$ & $\begin{array}{c}23 \\
(20,7 \%)\end{array}$ & $\begin{array}{c}35 \\
(31,5 \%)\end{array}$ & $\begin{array}{c}29 \\
(26,1 \%)\end{array}$ \\
\hline Afraid of the possibility to feel that the child is not really mine. & $\begin{array}{c}27 \\
(24,3 \%)\end{array}$ & $\begin{array}{c}31 \\
(27,9 \%)\end{array}$ & $\begin{array}{c}17 \\
(15,3 \%)\end{array}$ & $\begin{array}{c}22 \\
(19,8 \%)\end{array}$ & $\begin{array}{c}14 \\
(12,6 \%)\end{array}$ \\
\hline $\begin{array}{l}\text { What would increase the probability of becoming a sperm } \\
\text { donor? }\end{array}$ & $\begin{array}{c}1 \\
\text { Tottaly } \\
\text { disagree }\end{array}$ & 2 & 3 & 4 & $\begin{array}{c}5 \\
\text { Tottaly } \\
\text { agree }\end{array}$ \\
\hline Have counseling. & $\begin{array}{c}18 \\
(16.2 \%)\end{array}$ & $\begin{array}{c}14 \\
(12.6 \%)\end{array}$ & $\begin{array}{c}31 \\
(27.9 \%)\end{array}$ & $\begin{array}{l}30 \\
(27.0 \%)\end{array}$ & $\begin{array}{c}18 \\
(16.2 \%)\end{array}$ \\
\hline To donate in an IVF centre located in my residence area & $\begin{array}{c}20 \\
(18.0 \%)\end{array}$ & $\begin{array}{c}17 \\
(15.3 \%)\end{array}$ & $\begin{array}{c}27 \\
(24.3 \%)\end{array}$ & $\begin{array}{c}27 \\
(24.3 \%)\end{array}$ & $\begin{array}{c}20 \\
(18.0 \%)\end{array}$ \\
\hline Have more information about infertility. & $\begin{array}{c}21 \\
(18.9 \%)\end{array}$ & $\begin{array}{c}15 \\
(13.5 \%) \quad(\end{array}$ & $\begin{array}{c}31 \\
(27.9 \%)\end{array}$ & $\begin{array}{l}24 \\
(21.6 \%)\end{array}$ & $\begin{array}{c}20 \\
(18.0 \%)\end{array}$ \\
\hline
\end{tabular}

\section{Conclusion}

In this study, we a positive attitude of men regarding both gamete donation and surrogacy, expressing growing interest and responsibility about parenting was found, in accordance to another recent study (Bracewell-Milnes, Saso, Bora, Ismail, AlMenar, Hamed, \& Thum, 2016). However, the importance of greater information and counselling on these topics is equally pointed. Moreover, it seems essential to increase awareness and dissemination of information regarding fertility in order to elucidate eventual biased beliefs and/or clarify procedures related to these techniques, thus increasing adherence to sperm donation programs, either as a donor or as an intended father. Thus, developing strategies and platforms about (in) fertility seems to be important, as wells as providing tools to primary health care professionals due to the privileged contact with general population (Gentry, Pagidas \& Johnson, 2016).
The majority of participants $(82.9 \% ; n=92)$ would be willing to donate their sperm and their main motivation for doing that would be to feel "happy to help a couple struggling to have a child". Regarding sperm donation, more than $40,0 \%(n=37)$ of participants were not afraid of the possibility to be contacted later.

Participants stated that the likelihood of donating would increase if they were able to attend counselling. Regarding surrogacy, $82.7 \%(n=91)$ are in favour of this procedure legalization and $49.5 \%(n=55)$ would be willing to use it if they needed. "Glad to take care of a child since birth" was referred by $85.5 \%(n=47)$ of men as the way they would feel if they had to apply for a gestational carrier and $76.3 \%(n=42)$ would feel "Happy to fulfil their dream of being a father".

Participants revealed that they would not be afraid to ever feel that the child was not really theirs whether they would use gamete donation $(52.2 \% ; n=58)$ or surrogacy $(69.1 \% ; n=38)$.

\begin{tabular}{|l|c|cc}
$\begin{array}{c}\text { Do you agree with } \\
\text { surrogacy legalization? }\end{array}$ & $\boldsymbol{n}(\%)$ & $\begin{array}{c}\text { If you were not able to have a child } \\
\text { spontaneously, would you consider surrogacy? }\end{array}$ & $\boldsymbol{n}(\%)$ \\
\hline Yes & $91(82.7 \%)$ & Yes & $55(49.5 \%)$ \\
\hline No & $19(17.3 \%)$ & No & $56(50.5 \%)$ \\
\hline
\end{tabular}

\begin{tabular}{|c|c|c|c|c|c|}
\hline What do you think about surrogacy? & $\begin{array}{c}1 \\
\text { Tottaly } \\
\text { disagre }\end{array}$ & e & 3 & 4 & $\begin{array}{c}\mathbf{5} \\
\text { Tottaly } \\
\text { agree }\end{array}$ \\
\hline $\begin{array}{l}\text { If a friend needed to apply for surrogacy I would } \\
\text { support his/her decision. }\end{array}$ & $\begin{array}{c}1 \\
(1.2 \%)\end{array}$ & $\begin{array}{c}1 \\
(1.2 \%)\end{array}$ & $\begin{array}{c}9 \\
(10.7 \%)\end{array}$ & $\begin{array}{c}29 \\
(34.5 \%)\end{array}$ & $\begin{array}{c}44 \\
(52.4 \%)\end{array}$ \\
\hline $\begin{array}{l}\text { If a friend decided to act as a gestational surrogate I } \\
\text { would support her decision. }\end{array}$ & $\begin{array}{c}1 \\
(1.2 \%)\end{array}$ & $\begin{array}{c}4 \\
(4.8 \%)\end{array}$ & $\begin{array}{c}17 \\
(20.2 \%)\end{array}$ & $\begin{array}{c}24 \\
(28.6 \%)\end{array}$ & $\begin{array}{c}38 \\
(45.2 \%)\end{array}$ \\
\hline $\begin{array}{l}\text { If facing infertility, how would you feel about } \\
\text { the possibility of applying for surrogacy? }\end{array}$ & $\begin{array}{c}1 \\
\text { Tottaly } \\
\text { disagree }\end{array}$ & 2 & 3 & 4 & $\begin{array}{c}5 \\
\text { Tottaly } \\
\text { agree }\end{array}$ \\
\hline tappy to fulfil my dream of being a father. & & $\begin{array}{c}3 \\
(5.5 \%)\end{array}$ & $\begin{array}{c}10 \\
(18.2 \%)\end{array}$ & $\begin{array}{c}18 \\
(32.7 \%)\end{array}$ & $\begin{array}{c}24 \\
(43.6 \%)\end{array}$ \\
\hline Glad to take care of a child since birth. & & $\begin{array}{c}1 \\
(1.8 \%)\end{array}$ & $7(12.7 \%)$ & $\begin{array}{c}22 \\
(40.0 \%)\end{array}$ & $\begin{array}{l}25 \\
(45.5 \%)\end{array}$ \\
\hline $\begin{array}{l}\text { Afraid of the possibility to feel that the child is not } \\
\text { really mine. }\end{array}$ & $\begin{array}{l}20 \\
(36.4 \%)\end{array}$ & $\begin{array}{c}18 \\
(32.7 \%)\end{array}$ & $\begin{array}{c}10 \\
(18.2 \%)\end{array}$ & $\begin{array}{c}4 \\
(7.3 \%)\end{array}$ & $\begin{array}{c}3 \\
(5.5 \%)\end{array}$ \\
\hline
\end{tabular}

Hanna, E., \& Gough, B. (2015). Experiencing Male Infertility: A Review of the Qualitative Research Literature. Sage Open, 22, pp: 1 - 9. dol

Gentry, A.L., Pagidas, K., \& Johnson I. (2016). Perspectives on the Management of Infertility in Primary Care: A Survey of Healthcare Providers in a Regional Health 